\title{
Nitrogen and atrazine on shortgrass: Vegetation, cattle and economic responses
}

\author{
RICHARD H. HART, MARVIN C. SHOOP, AND MARY M. ASHBY
}

\begin{abstract}
Authors are Range Scientist, USDA-ARS, Rangeland Resources Research Unit, High Plains Grasslands Research Station, 8408 Hildreth Road, Cheyenne, Wyo. 82009; retired Range Scientist, formerly USDA-ARS, Central Plains Experimental Range, now 408 Junco Court, Fr. Collins, Colo. 80526; and Range Technician, USDA-ARS, RRRU, CPER, 58009 County Road 37, Numn, Colo. 80648. The study was conducted by Shoop; after his retirement, the data was analysed and interpreted by Hart. Ashby assisted in all phases of the study.
\end{abstract}

\begin{abstract}
Application of nitrogen $(\mathrm{N})$ fertilizer and atrazine [6-chloro- $\mathrm{N}$ ethyl- $N^{\prime}$-(1-methylethyl)-1,3,5-triazine-2,4-diamine] have each increased grazeable forage on shortgrass prairie, but their effects are unknown when applied in combination. Therefore, a 9-year study was conducted to determine effects of $\mathrm{N}$ and atrazine applications on 1) herbage production, 2) steer gains, and 3) profitability of grazing on shortgrass prairie in north-central Colorado. Treatments were 1) untreated control, 2) atrazine applied at $1.1 \mathrm{~kg} \mathrm{ha}^{-1}$ in the autumn of alternate years, 3) $\mathrm{N}$ applied at $22 \mathrm{~kg} \mathrm{ha}^{-1}$ each autumn, and 4) $\mathrm{N}+$ atrazine at the rates specified above. Pastures were stocked at 21-41 (control), 27-54 (atrazine), 24-82 (N), or 18-84 (N + atrazine) cattle-days $\mathrm{ha}^{-1}$ during summer. Pastures were stocked with yearling steers 1979-1983 and yearling steers and spayed heifers 1984-1985, using put-and-take stocking. All treatments increased total October standing crop and blue grama (Bouteloua gracilis [H.B.K.] Lag. ex Griffiths) standing crop. Nitrogen increased cool-season grass and forb standing crops; atrazine nearly eliminated cool-season grasses but did not affect forbs. Under putand-take stocking, atrazine and/or $\mathrm{N}$ appeared to increase stocking rate and gain/ha, but not average daily gain or average returns to land, labor, and management. Under optimum stocking rates and grazing strategies, $\mathrm{N}$ or atrazine but not both together might increase returns.
\end{abstract}

Key Words: blue grama, fertilization, grazing, herbicide, intensive early stocking, put-and-take grazing, weed control, 6-chloro$N$-ethyl- $N^{\prime}$-(1-methylethyl)-1,3,5-triazine-2,4-diamine

Although nitrogen $(\mathbb{N})$ fertilization and herbicide application often have increased forage production on rangelands, livestock

This paper reports cooperative research by USDA-ARS, Crow Valley Livestock Cooperative, Inc, and Colorado State University Agricultural Experiment Station.

Authors gratefully acknowledge the support of CIBA-GEIGY, who supplied atrazine. Wycon Chemical Co. (now Coastal Chem Inc.), Cheyenne, Wyo.; Simplot Soilbuilders, Pocatello, Ida.; American Fertilizer \& Chemical Co., Henderson, Colo.; and CPER/TER Shortgrass Steppe Program (NSF Grant BSR \$612105) supplied nitrogen fertilizer. D. N. Hyder and W. R. Houston, retired Range Scientists, USDA-ARS, helped plan the study, and Gary V. Richardson, Statistician, USDA-ARS, Northem Plains Area, Ft. Collins, Colo. advised on statistical analysis.

Manuscript accepted 29 Aug. 1994. producers have been reluctant to use them because of uncertainty about profitability. Nitrogen applied at $22 \mathrm{~kg} \mathrm{ha}^{-1}$ to shortgrass prairie nearly doubled beef production in a study on heavily grazed miniature pastures (Hyder et al. 1975). Each additional kilogram of liveweight gain obtained from applying $\mathrm{N}$ returned about $\$ 0.55$ above fertilization costs. Despite the potential for increasing profits, $\mathrm{N}$ has increased drought mortality of blue grama (Bouteloua gracilis [H.B.K.] Lag. ex Griffiths), and has increased abundance of annual forbs and sixweeks grass (Vulpia octoflora Rydb.), an unpalatable annual grass. The effects of $\mathrm{N}$ plus a herbicide on production and profitability of shortgrass prairie are unknown.

Earlier researchers determined that application of atrazine [6chloro- $N$-ethyl- $N$-(1-methylethyl)-1,3,5-triazine-2,4-diamine] benefited vegetation on shortgrass range in 3 ways. Atrazine controlled annual plants (Houston 1977), increased crude protein content of grasses (Houston and van der Sluijs 1973), and reduced blue grama susceptibility to drought mortality (Hyder et al. 1976). Some members of the $s$-triazine family of compounds, to which atrazine belongs, have increased yield of some forage species (Ries 1976). Demonstration that atrazine could materially increase herbage production on rangelands could lead to study of similar compounds to increase herbage yields. Manufacturers have not yet applied to the Environmental Protection Agency (EPA) to relabel atrazine, a restricted-use pesticide for agriculture, for use on rangelands in the United States. Knowledge of the effects of applying $s$-triazine herbicides to rangeland, alone or with $\mathrm{N}$, and over long periods, is needed.

This study was conducted to determine the effects of treating native shortgrass range with $\mathrm{N}$ and atrazine alone and in combination on herbage production, steer gains and net return to a stocker steer enterprise. As an unintended consequence, the study demonstrated the difficulty of interpreting data from grazing experiments using put-and-take stocking.

\section{Materials and Methods}

\section{Study Site}

The study was conducted from 1977-1985 (1977 and 1978 data were incomplete; only 1979-1985 data will be reported) on the Central Plains Experimental Range. The Range is at $40^{\circ} 50^{\circ} \mathrm{N}$, 
$104^{\circ} 43^{\prime} \mathrm{W}$, about $40 \mathrm{~km}$ northeast of Fort Collins, Colo. near the western edge of the shortgrass plains. Precipitation during the growing season was below the 54-year average during 1985; average during 1980; and above average during all other years (Table 1). Soils were primarily Ascalon fine sandy loam (mixed, mesic Aridic Argiustoll) and Vona sandy loam (mixed, mesic Ustollic Haplargids). Both soils have a $\mathrm{pH}$ of about 6.6 in the surface $5-\mathrm{cm}$ layer and 7.8 at $50 \mathrm{~cm}$.

Table 1. Precipitation at the Central Plains Experimental Range.

\begin{tabular}{|c|c|c|}
\hline Growing season & $\begin{array}{l}1 \text { April- } \\
30 \text { Sep }\end{array}$ & $\begin{array}{l}\text { Preceding } 1 \text { Oct- } \\
30 \text { Sep }\end{array}$ \\
\hline & \multicolumn{2}{|c|}{ - $\ldots$ - Prccipitation, mm $\ldots$} \\
\hline 1979 & 397 & 472 \\
\hline 1980 & 263 & 410 \\
\hline 1981 & 334 & 380 \\
\hline 1982 & 423 & 510 \\
\hline 1983 & 345 & 424 \\
\hline 1984 & 362 & 449 \\
\hline 1985 & 225 & 320 \\
\hline $1937-1985$ mean & 261 & 320 \\
\hline
\end{tabular}

Blue grama was the dominant forage species on all soils. Vona soils initially supported about 2,500 fourwing saltbush (Atriplex canescens [Pursh] Nutt.) plants $\mathrm{ha}^{-1}$ and a small amount of coolseason grasses, mostly westem wheatgrass (Pascopyrum smithii [Rydb.] A. Love), and needleandthread (Stipa comata Trin. \& Rupr.). Ascalon soils generally supported few cool-season grasses. Annual grasses were rare during the study. Common forbs included scarlet globemallow (Sphaeralcea coccinea [Pursh.] Rydb.), miner's candles (Cryptantha spp.), stickseeds (Lappula spp.), prairie spiderwort (Tradescantia occidentalis [Britt.] Smyth), and prairie pepperweed (Lepidium densiflorum Schrad.) Plains pricklypear (Opuntia polyacantha Haw.) was also common.

\section{Treatments}

Treatments were 1] control, 2] atrazine at $1.1 \mathrm{~kg} \mathrm{ha}^{-1}$ a.i., 3] nitrogen $(\mathrm{N})$ fertilizer at $22 \mathrm{~kg} \mathrm{ha}^{-1}$ of $\mathrm{N}$, and 4$] \mathrm{N}+$ atrazine, both at the above rates. On the $\mathrm{N}$ and $\mathrm{N}+$ atrazine treatments, ammonium nitrate was broadcast between 16 October and 20 November each year except 1977. The application scheduled for 1977 was postponed until after rain in May 1978, because applying $N$ could have intensified drought mortality of blue grama (Hyder et al. 1975). Atrazine was applied to dormant vegetation in October or November of 1976, 1978, 1979, 1981, and 1983 in $7.61 \mathrm{ha}^{-1}$ of water.

The control and atrazine treatments were assigned to 64.8-ha pastures, and the $\mathrm{N}$ and $\mathrm{N}+$ atrazine treatments to 32.4-ha pastures. Each treatment was applied to 2 pastures; the pastures were arranged in 2 randomized blocks, an east and west block. East block pastures had been lightly grazed during the summers of 1957-1973. West block pastures had been moderately grazed during the winters of the same years, except for the control pasture which had been moderately grazed during summers. All pastures were moderately grazed during the summers of 1974-1976. No chemical or mechanical treatments had been applied 1938-1975.

\section{Vegetation Measurements}

Current standing crop of herbage was estimated on grazed and exclosed areas of each pasture in October of 1979-1985. Estimates were to a precision of $<10 \%$ of the mean of total herbage, using the micro-unit forage inventory method (Shoop and McIlvain 1963). Two quadrats were estimated inside and 2 outside of each of 80 exclosures/pasture, with every fifth quadrat clipped, dried, and weighed as well as estimated to develop equations for correcting estimated values. Standing crop is expressed as oven-dry weight. Standing crop outside exclosures was similarly estimated each time cattle were weighed.

\section{Livestock and Grazing Management}

In 1979 through 1983, pastures were stocked about 1 June each year with 12- to 15-month-old Hereford steers. In 1984 and 1985 , only about half the animals in each pasture were steers; the other half were spayed heifers, weighing an average of $174 \mathrm{~kg}$ in 1984 and $223 \mathrm{~kg}$ in 1985 . Average steer weights ranged from 210 to $243 \mathrm{~kg}$. Put-and-take cattle were added or removed to adjust stocking needs (Fig. 1), as determined from herbage estimates each time the steers were weighed.

All steers were implanted with Ralgro' before grazing began. Grazing continued into October each year; the goal was to reduce the herbage remaining to about $400 \mathrm{~kg} \mathrm{ha}^{-1}$, an amount slightly above the level recommended by Bement (1969). Grazing seasons lasted an average of 132 days.

Average daily gain and gain ha $\mathrm{a}^{-1}$ were calculated from total gains of all cattle on each pasture during the grazing season. At the beginning and end of the grazing season, weights of each animal were the average of 2 weights taken at 5-day intervals. Weights during the season are single-day weights.

\section{Economic Analysis}

Returns to land, labor and management were calculated using recent prices for cattle, fertilizer, atrazine, application, and miscellaneous costs. Cattle prices were taken from the weekly market reports in Bridges $(1992,1993)$ and fitted to a response surface (Table 2) in which price was the dependent variable and date and cattle weight were the independent variables. The equation of the response surface was used to calculate the value of each animal, according to its weight and the date, when it was put on pasture and again when it was removed. The sum of these changes in value represented the gross return to the pasture. Sands and Robb (1993) calculated "other expenses (interest, marketing, health care, etc.) of $\$ 55$...for a 550 -pound $(250-\mathrm{kg}$ ) feeder steer ...over a 5 -month grazing season," equivalent to $\$ 0.36 /$ day. Hart et al. (1988) calculated similar costs from data of Jose et al. (1985). These expenses and the costs of nitrogen, atrazine, and their application were subtracted from gross returns to provide net returns to land, labor, and management.

Fertilizer, herbicide, and application costs were supplied by Jirdon Agrichem, Torrington, Wyo. Ammonium nitrate cost $\$ 0.208 \mathrm{~kg}^{-1}\left(\$ 189\right.$ ton $\left.^{-1}\right)$ plus $\$ 7.50 \mathrm{ha}^{-1}\left(\$ 3.00 \mathrm{~A}^{-1}\right)$ to apply. Atrazine cost $\$ 9.61 \mathrm{~kg}^{-1}$ a.i. ( $\$ 15.00 \mathrm{gal}^{-1}$, $43 \%$ a.i.) plus $\$ 8.75 \mathrm{ha}^{-1}$ $\left(\$ 3.50 \mathrm{~A}^{-1}\right)$ to apply. Annual atrazine cost was only $\$ 9.66 \mathrm{ha}^{-1}$ because it was applied approximately every 2 years.

\footnotetext{
${ }^{1}$ Mention of a trademark or proprietary product does not constitute a guarantee or warranty of the product by the U.S. Department of Agriculture, and does not imply its approval to the exclusion of other products that may also be suitable.
} 
Statistical Analysis

The study was conducted as a randomized complete block with 2 replications and repeated measurements over years, which were treated as split-plots. Data were subjected to analysis of variance; when significant differences among means were indicated, means were separated by Duncan's multiple range test (Hruschka 1973) at $P<0.05$.

In 1979 through 1982, when initial stocking rates on all pastures were increased as the season progressed, a strong relationship was apparent between average daily gain and grazing pressure. This relationship was defined by standard regression methods.

\section{Results and Discussion}

\section{Herbage Production and Botanical Composition}

Nitrogen or atrazine increased October standing crop of blue grama by about half; $\mathrm{N}+$ atrazine increased blue grama $77 \%$ (Table 3). Years were a significant source of variation in total forage production (Table 4), but the treatment $\times$ year interaction was non-significant. Nitrogen alone doubled standing crop of cool-season grasses and nearly tripled standing crop of forbs, while atrazine alone or with $\mathrm{N}$ had no effect on forbs and nearly eliminated cool-season grasses. Atrazine and $\mathrm{N}+$ atrazine did not significantly reduce forbs below the control level in the current study because the crop of forbs was very small on all 3 treatments. Although atrazine alone did not reduce the forb standing crop below that on the control, reduction of forbs by atrazine was obvious in areas along fences between treatments. Atrazine reduced annual but not perennial forbs in a 3-year study at CPER (Houston 1977).
Standing crop left at the end of the grazing season ranged from a mean of $327 \mathrm{~kg} \mathrm{ha}^{-1}$ with $\mathrm{N}+$ atrazine to $383 \mathrm{~kg} \mathrm{ha}{ }^{-1}$ with nitrogen alone. Residual forage was somewhat less than the $400 \mathrm{~kg} \mathrm{ha}^{-1}$ objective of this study, but slightly more than the $335 \mathrm{~kg} \mathrm{ha}{ }^{-1}$ ( 300 $\mathrm{lb} \mathrm{A}^{-1}$ ) recommended by Bement (1969). Utilization (standing crop minus residual divided by standing crop) ranged from $34 \%$ on the control to $60 \%$ on $\mathrm{N}+$ atrazine. Utilization on the latter was higher than the common "take half, leave half" recommendation, but did not appear to reduce average daily gain.

The increase in total herbage standing crop by $\mathrm{N}$ over the control was caused by a large increase in the standing crop of blue grama and small increases in standing crops of cool-season grasses and forbs (Table 3). Application of $\mathrm{N}$ at $22 \mathrm{~kg} \mathrm{ha}^{-1}$ in an earlier CPER study increased abundance of western wheatgrass, a coolseason grass, $66 \%$ over the control and increased abundance of some forbs when weather conditions favored their growth (Hyder et al. 1975). The increase in herbage production from $\mathrm{N}$ fertilization in the current study is consistent with other studies on ranges where blue grama is the dominant grass. Nitrogen at rates up to $45 \mathrm{~kg} \mathrm{ha}^{-1}$ increased herbage production as much as $71 \%$ (Hyder and Bement 1964, Rauzi et al. 1968, Dwyer and Schickendanz 1971, Donart et al. 1978). Increased blue grama production from $\mathrm{N}+$ atrazine over $\mathrm{N}$ alone appears to be partially related to a combination of the increased drought mortality of blue grama caused by $\mathrm{N}$ and the drought-reducing effect of atrazine (Hyder et al. 1975, Hyder et al. 1976).

Increases in total herbage standing crop by atrazine and $\mathrm{N}+$ atrazine over the control were caused entirely by increases in blue grama and occurred in spite of reductions in cool-season grasses (Table 3). Application of atrazine in another CPER study (Houston 1977) also reduced abundance of cool-season grasses. On typical shortgrass range, most cool-season grasses could be

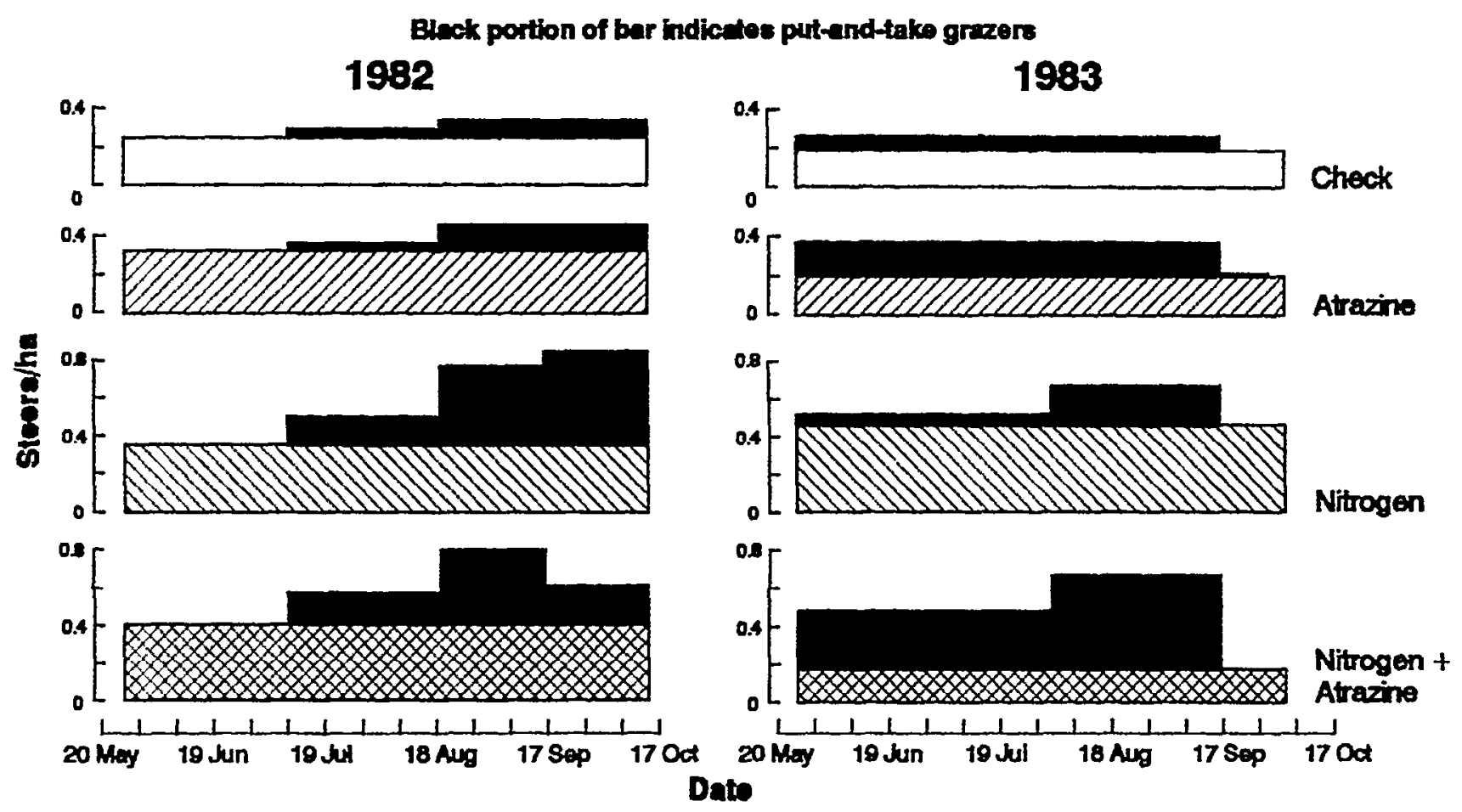

Fig. 1. Seasonal stocking patterns, 1982 and 1983. 
Table 2. Steer weights, dates, and steer prices; data from Bridges $(1992,1993)$. Price $=\$ 131.94+(2093 /$ date $)+(16402 /$ weight $)$.

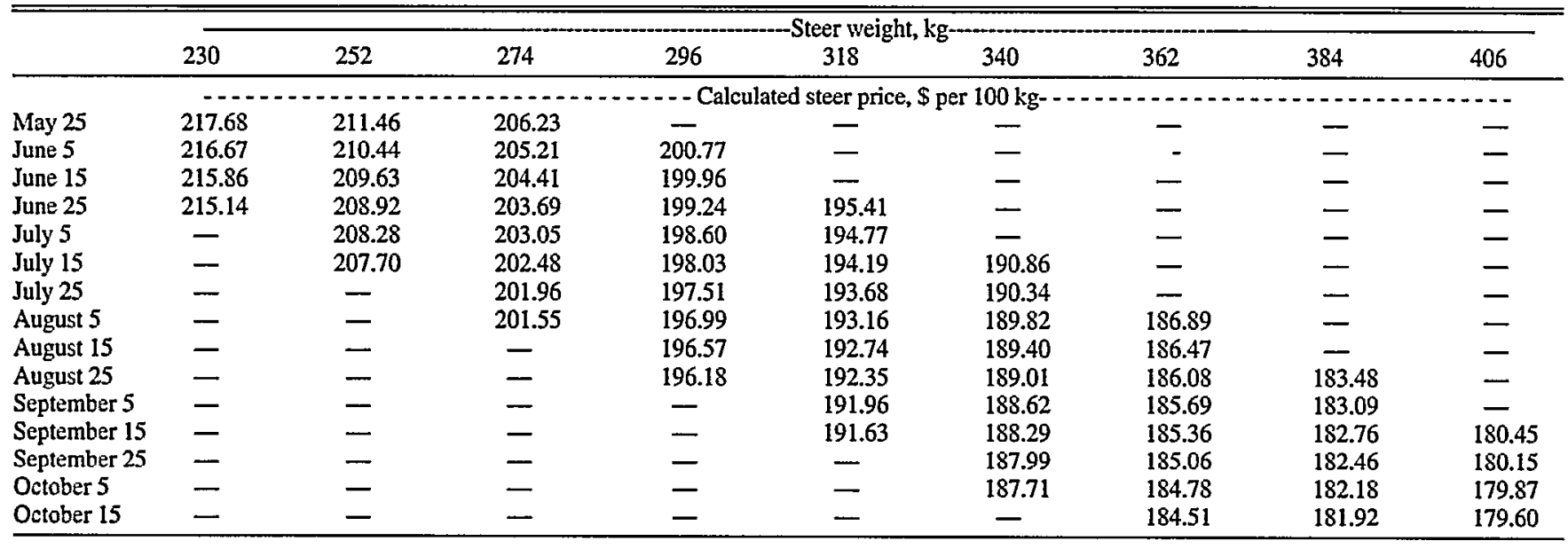

retained by avoiding application of atrazine to sites where they grow, such as sandy or run-on sites. Plots in an earlier CPER study treated with simazine, another $s$-triazine herbicide, were preferentially grazed by cattle over nontreated plots (Hyder and Bement 1964). Eliminating atrazine application to areas with appreciable amounts of cool-season grasses might be a desirable practice to reduce grazing pressure on these grasses.

Reducing the standing crop of annual plants and cool-season grasses by applying atrazine probably did little to increase standing crop of blue grama. The proportion of annuals and cool-season grasses before atrazine application was too small to provide significant competition. Forb standing crop did not differ in any year between control and atrazine treatments, and the difference in standing crop of cool-season grasses, although significant, was small (29 kg ha-1). Various $s$-triazine treatments increased total herbage production up to $60 \%$ in plot studies at CPER (Hyder and Bement 1964, Tapia 1973, Houston and van der Sluijs 1973) and increased total herbage elsewhere (Ries 1976, Waller and Schmidt 1983, Currie et al. 1987). These reports did not contain data upon which to judge whether increases in total herbage were caused by herbicidal reduction of competition or by some other response to an $s$-triazine. Some $s$-triazine treatments have not increased total herbage production, especially where application rates were relatively high or when annual plants or $s$-triazine-susceptible grasses were abundant (Allinson 1972, Houston and van der Sluijs 1973, McConnell and Waller 1986).

Table 3. October standing crop, excluding plains pricklypear and shrubs, 1979-1985.

\begin{tabular}{|c|c|c|c|c|}
\hline Species or group & Control & Atrazine & Nitrogen & $\begin{array}{l}\text { Nitrogen + } \\
\text { atrazine }\end{array}$ \\
\hline & \multicolumn{4}{|c|}{$\ldots \ldots-k g / h a-\ldots \ldots$} \\
\hline Blue grama & $450 c^{1}$ & $710 \mathrm{b0}$ & $680 \mathrm{~b}$ & $800 \mathrm{a}$ \\
\hline Cool-season grasses & $40 \mathrm{~b}$ & $10 \mathrm{c}$ & $80 a$ & $10 \mathrm{c}$ \\
\hline Other grasses & $80 a$ & $50 \mathrm{a}$ & $60 \mathrm{a}$ & $70 \mathrm{a}$ \\
\hline Total grasses & $570 \mathrm{c}$ & $760 b$ & $820 a b$ & $880 a$ \\
\hline Forbs & $40 \mathrm{~b}$ & $30 \mathrm{~b}$ & $130 \mathrm{a}$ & $40 \mathrm{~b}$ \\
\hline
\end{tabular}

istanding crop figures within a species or species group, followed by the same letter, are not significantly different $(P \leq 0.05)$.

\section{Cattle Gains}

Average daily gains (ADG) of cattle did not differ significantly among treatments in any year or over all years (Table 4). Gains may have been reduced in 1984 and 1985 because cattle were about half steers and half spayed heifers. Shoop et al. (1984) reported that spayed heifers pastured with zeranol-implanted steers gained $0.78 \mathrm{~kg}$ day ${ }^{-1}$ while the steers gained $0.88 \mathrm{~kg}$ day ${ }^{-1}$. In 1984, among cattle which remained on the pastures for the entire grazing season, heifers gained $0.81 \mathrm{~kg}^{\text {day-1 }}{ }^{-1} 0.92 \mathrm{~kg}^{\mathrm{day}}{ }^{1}$ for steers. It was not possible to make a season-long comparison in 1985 because all the steers were removed from all the pastures from 18 June to 7 August and only heifers grazed the pastures during that time.

Nitrogen fertilization of other ranges with a major blue grama component also has increased gain per head, carrying capacity, and total beef production over no fertilization (Dwyer and Schickendanz 1971, Retzlaff et al. 1974, Donart et al. 1978). In an earlier CPER experiment in which 1.4-ha pastures were grazed heavily for various 1-month periods each summer, $\mathrm{N}$ applied at $22 \mathrm{~kg} \mathrm{ha}^{-1}$ increased steer days of grazing 17 days ha-1 and daily gain by $0.15 \mathrm{~kg} \mathrm{head}^{-1}$ (Hyder et al. 1975). The increase in days of grazing on moderately grazed range in the current study was greater than that reported by Hyder et al. (1975), but daily gain did not increase.

Average daily gains of cattle in the current study (Table 3) were much higher than gains reported by Klipple and Costello (1960) in a study of 3 grazing intensities, but they grazed heifers for 175 to 184 days whereas we grazed mostly steers, treated with Ralgro, for 132 days in the present study. All these factors increased gains in the present study over those reported by Klipple and Costello (1960). Gains probably were much reduced in the last month or so of the Klipple and Costello (1960) study. Klipple (1964) found that ADG of a mixture of steers and heifers, beginning on the tenth of each month, were $0.92,0.89,0.84,0.73$, 0.60 , and $0.12 \mathrm{~kg}$ in May, June, July, August, September, and October, respectively.

Under set-stocking, maximum heifer gains of $0.66 \mathrm{~kg} \mathrm{day}^{-1}$ were reached at about 23 heifer-days ha.-1 (Bement 1969) on unfertilized range producing about $600 \mathrm{~kg} \mathrm{ha}^{-1} \mathrm{yr}^{-1}$ at the CPER (unpublished data). As in the Klipple and Costello (1960) study, 
Table 4. Vegetation, management, steer gain, and returns to land, labor and management, 1979-1985.

\begin{tabular}{|c|c|c|c|c|c|c|}
\hline $\begin{array}{l}\text { Year } \\
\text { \& man. }\end{array}$ & Treatment & $\begin{array}{l}\text { October } \\
\text { standing } \\
\text { crop }\end{array}$ & $\begin{array}{l}\text { Stock-- } \\
\text { ing rate }\end{array}$ & & $\begin{array}{l}\text { Gain } \\
\text { ADG }\end{array}$ & $\begin{array}{l}\text { Retum to } \\
\text { land, labor } \\
\text { ha't } \\
\text { agement }\end{array}$ \\
\hline 1979 & $\begin{array}{l}\text { Check } \\
\text { Atrazine } \\
\text { Nitrogen } \\
N+\text { atrazine } \\
\text { Mean }\end{array}$ & $\begin{array}{c}\mathrm{kg} \mathrm{ha}^{-1} \\
540 \\
698 \\
986 \\
864 \\
772 \mathrm{C}\end{array}$ & $\begin{array}{c}\begin{array}{c}\text { Cattle } \\
\text { days ha-1 }\end{array} \\
21.1 \mathrm{a}^{2} \\
26.7 \mathrm{a} \\
25.6 \mathrm{a} \\
28.9 \mathrm{a}\end{array}$ & $\begin{array}{l}\mathrm{kg} \\
1.00 \\
0.99 \\
1.04 \\
1.01 \\
1.01 \mathrm{~A}\end{array}$ & $\begin{array}{c}\mathrm{kg} \\
21.6 \mathrm{a} \\
26.3 \mathrm{a} \\
26.4 \mathrm{a} \\
28.9 \mathrm{a}\end{array}$ & $\begin{array}{l}\$ h^{-1} \\
21.68 \mathrm{a} \\
14.62 \mathrm{~b} \\
3.76 \mathrm{c} \\
-3.82 \mathrm{c}\end{array}$ \\
\hline 1980 & $\begin{array}{l}\text { Check } \\
\text { Atrazine } \\
\text { Nitrogen } \\
N+\text { atrazine } \\
\text { Mean }\end{array}$ & $\begin{array}{l}549 \\
576 \\
783 \\
588 \\
624 \mathrm{C}\end{array}$ & $\begin{array}{l}29.2 \mathrm{~b} \\
40.2 \mathrm{ab} \\
43.8 \mathrm{a} \\
47.8 \mathrm{a}\end{array}$ & $\begin{array}{l}0.78 \\
0.78 \\
0.87 \\
0.69 \\
0.78 \mathrm{D}\end{array}$ & $\begin{array}{l}22.8 \mathrm{~b} \\
31.4 \mathrm{ab} \\
37.9 \mathrm{a} \\
33.0 \mathrm{a}\end{array}$ & $\begin{array}{l}18.20 \mathrm{a} \\
15.52 \mathrm{a} \\
11.70 \mathrm{a} \\
-6.71 \mathrm{~b}\end{array}$ \\
\hline 1981 & $\begin{array}{l}\text { Check } \\
\text { Atrazine } \\
\text { Nitrogen } \\
N+\text { atrazine } \\
\text { Mean }\end{array}$ & $\begin{array}{c}712 \\
1042 \\
993 \\
1053 \\
950 \mathrm{AB}\end{array}$ & $\begin{array}{l}37.3 \mathrm{~b} \\
50.5 \mathrm{ab} \\
55.8 \mathrm{a} \\
56.1 \mathrm{a}\end{array}$ & $\begin{array}{l}0.68 \\
0.76 \\
0.80 \\
0.81 \\
0.76 \mathrm{D}\end{array}$ & $\begin{array}{l}25.7 \mathrm{~b} \\
38.2 \mathrm{ab} \\
44.7 \mathrm{a} \\
45.6 \mathrm{a}\end{array}$ & $\begin{array}{l}18.16 \mathrm{a} \\
19.87 \mathrm{a} \\
15.22 \mathrm{ab} \\
11.45 \mathrm{~b}\end{array}$ \\
\hline 1982 & $\begin{array}{l}\text { Check } \\
\text { Atrazine } \\
\text { Nitrogen } \\
\mathrm{N}+\text { atrazine } \\
\text { Mean }\end{array}$ & $\begin{array}{c}704 \\
993 \\
1150 \\
1339 \\
1047 \mathrm{~A}\end{array}$ & $\begin{array}{l}41.3 \mathrm{c} \\
54.0 \mathrm{~b} \\
82.0 \mathrm{a} \\
83.6 \mathrm{a}\end{array}$ & $\begin{array}{l}0.72 \\
0.76 \\
0.74 \\
0.71 \\
0.73 \mathrm{D}\end{array}$ & $\begin{array}{l}29.7 \mathrm{c} \\
40.7 \mathrm{~b} \\
60.9 \mathrm{a} \\
58.6 \mathrm{a}\end{array}$ & $\begin{array}{l}22.16 \mathrm{a} \\
21.98 \mathrm{a} \\
26.17 \mathrm{a} \\
12.39 \mathrm{~b}\end{array}$ \\
\hline 1983 & $\begin{array}{l}\text { Check } \\
\text { Atrazine } \\
\text { Nitrogen } \\
\mathrm{N}+\text { atrazine } \\
\text { Mean }\end{array}$ & $\begin{array}{c}589 \\
755 \\
1010 \\
857 \\
803 \mathrm{BC}\end{array}$ & $\begin{array}{l}35.0 \mathrm{~b} \\
48.7 \mathrm{~b} \\
70.1 \mathrm{a} \\
69.4 \mathrm{a}\end{array}$ & $\begin{array}{l}0.96 \\
0.96 \\
0.94 \\
0.97 \\
0.96 \mathrm{~B}\end{array}$ & $\begin{array}{l}33.4 \mathrm{~b} \\
46.6 \mathrm{~b} \\
66.5 \mathrm{a} \\
67.4 \mathrm{a}\end{array}$ & $\begin{array}{l}30.08 \mathrm{~b} \\
31.25 \mathrm{~b} \\
38.81 \mathrm{a} \\
30.73 \mathrm{~b}\end{array}$ \\
\hline 1984 & $\begin{array}{l}\text { Check } \\
\text { Atrazine } \\
\text { Nitrogen } \\
\mathrm{N}+\text { atrazine } \\
\text { Mean }\end{array}$ & $\begin{array}{l}526 \\
612 \\
950 \\
891 \\
745 \mathrm{C}\end{array}$ & $\begin{array}{l}29.4 \mathrm{c} \\
43.6 \mathrm{~b} \\
64.6 \mathrm{a} \\
54.0 \mathrm{ab}\end{array}$ & $\begin{array}{l}0.98 \\
0.93 \\
0.85 \\
0.98 \\
0.93 \mathrm{~B}\end{array}$ & $\begin{array}{l}28.8 \mathrm{c} \\
40.8 \mathrm{~b} \\
55.4 \mathrm{a} \\
52.8 \mathrm{ab}\end{array}$ & $\begin{array}{l}25.91 \mathrm{a} \\
25.22 \mathrm{a} \\
26.67 \mathrm{a} \\
18.29 \mathrm{~b}\end{array}$ \\
\hline 1985 & $\begin{array}{l}\text { Check } \\
\text { Atrazine } \\
\text { Nitrogen } \\
\mathrm{N}+\text { atrazine } \\
\text { Mean }\end{array}$ & $\begin{array}{l}689 \\
874 \\
743 \\
809 \\
779 \mathrm{C}\end{array}$ & $\begin{array}{l}24.4 \mathrm{ab} \\
34.7 \mathrm{a} \\
23.5 \mathrm{ab} \\
18.4 \mathrm{~b}\end{array}$ & $\begin{array}{l}0.83 \\
0.88 \\
0.89 \\
0.94 \\
0.88 \mathrm{C}\end{array}$ & $\begin{array}{l}20.4 \mathrm{ab} \\
31.2 \mathrm{a} \\
21.2 \mathrm{ab} \\
17.2 \mathrm{~b}\end{array}$ & $\begin{array}{r}17.04 \mathrm{a} \\
15.20 \mathrm{a} \\
-2.43 \mathrm{~b} \\
-15.20 \mathrm{c}\end{array}$ \\
\hline Mean & $\begin{array}{l}\text { Check } \\
\text { Atrazine } \\
\text { Nitrogen } \\
N+\text { atrazine }\end{array}$ & $\begin{array}{l}616 \mathrm{X} \\
793 \mathrm{Y} \\
945 \mathrm{Z} \\
915 \mathrm{YZ}\end{array}$ & & $\begin{array}{l}0.85 \mathrm{Z} \\
0.87 \mathrm{Z} \\
0.88 \mathrm{Z} \\
0.87 \mathrm{Z}\end{array}$ & & $\begin{array}{r}21.88 \mathrm{Z} \\
20.52 \mathrm{Z} \\
21.70 \mathrm{Z} \\
6.73 \mathrm{Y}\end{array}$ \\
\hline
\end{tabular}

1 Ammonium nitrate costs $\$ 0.208 \mathrm{~kg}^{-1}\left(\$ 189 \mathrm{~T}^{\mathrm{i}}\right)+\$ 7.50 \mathrm{ha}^{-1}\left(\$ 3.00 / \mathrm{A}^{-1}\right)$ to apply, for a total cost of $\$ 20.96 \mathrm{ha}^{\mathrm{s}} \mathrm{yr}^{-3}$. Atrazine costs $\$ 9.61 \mathrm{~kg}^{3}$ a.i. (\$15.00 gal ', $43 \%$ a.i.) $+\$ 8.75$ $h^{\prime}{ }^{\prime}\left(\$ 3.50 \mathrm{~A}^{\prime}\right)$ to apply; total cost is only $\$ 9.66 \mathrm{ha}^{-1} \mathrm{yr}^{-1}$ because atrazine is applied every 2 years. Prices from Jirdon Agrichem, Torrington, Wyo.

Figures in the same column and year, followed by the same lower-case letter, and year means and treatment means, followed by the same upper-case letter (A-D and X-Z respectively) are not significantly different $(P<0.05)$.

heifers gain more slowly than steers and the grazing season was longer, 183 days ( 1 May to 31 October), than in the present study.

Ashby et al. (1993) reported gains of steers for 7 years under heavy stocking only and grazing seasons of 138 to 147 days. Average daily gain these 7 years was predicted by $A D G=0.665$ $0.00185 \mathrm{GP}$, when grazing pressure (GP) was expressed as steerdays $\mathrm{Mg}^{-1}$ of peak standing crop; $\mathrm{r}^{2}=0.25$. In the present study, $\mathrm{ADG}$ on the control pastures averaged $0.83 \mathrm{~kg}$ at a grazing pres- sure of 50.6 cattle-d $\mathrm{Mg}^{-1}$ of forage; calculated $\mathrm{ADG}$ at the same grazing pressure, using the equation of Ashby et al. (1993), was $0.57 \mathrm{~kg}$.

From 1979 through 1982, initial stocking rate was low and then was increased later in the grazing season; the stocking pattern in 1982 is illustrated in Figure 1. In these years, ADG decreased sharply and linearly as total stocking rate for the season increased (Fig. 2). Under this management, the highest stocking rates and grazing pressures occurred at the end of each grazing season when, as noted above, gains are much reduced. In 1983 and 1984, initial stocking rate was high but then was reduced later in the season; the stocking pattern in 1983 is also illustrated in Figure 1. In these years, ADG was not affected by grazing pressurc. The latter management is similar to intensive early stocking, which supports higher stocking rates and higher gains than set-stocking (McCollum et al. 1990, Owensby et al. 1988 and Smith and Owensby 1978).

\section{Economic Analysis}

Under put-and-take management and recent prices, estimated returns to land, labor and management were $6 \%, 1 \%$, and $69 \%$ less on the atrazine, $N$ and $N+$ atrazine pastures, respectively, than on the control pastures (Table 4). However, gains and returns were influenced by stocking rate decisions, by the time of year when cattle were added or subtracted from the pastures, and by differences among years, as well as by the impact of treatments on forage production.

Initially, we intended to base our economic analysis on gains $\mathrm{ha}^{-1}$ calculated by multiplying the average daily gain of the tester cattle (those that remained on the pastures season-long) by the number of cattle-days ha ${ }^{-1}$. Mott and Lucas (1952) point out that this is not a valid method because forage consumption rates and gains vary widely throughout the season. The gains of put-andtake animals, for whatever part of the season they are on the pasture, are seldom the same as the gains of tester animals for the entire season. For example, in 1982 large numbers of put-andtake animals were on the pastures only during the latter part of the season when gains were reduced, while in 1984 large numbers of put-and-take animals were on the pastures only during the first part of the season when gains were near maximum. In 1982, gain on the $\mathrm{N}+$ atrazine pastures was estimated at $70.5 \mathrm{~kg} \mathrm{ha}$ when tester gains were multiplied by cattle-days $\mathrm{ha}^{-1}$, but actual gain was only $58.6 \mathrm{~kg} \mathrm{ha}^{-1}$. In 1984 on the same pastures, gain was estimated at $48.6 \mathrm{~kg} \mathrm{ha}^{-1}$ when tester gains were multiplied by cattle-days ha-1, but actual gain was $52.8 \mathrm{~kg} \mathrm{ha}^{-1}$. Put-and-take animals contributed as little as $10 \%$ (control 1979) to as much as $68 \%(\mathrm{~N}+$ atrazine 1983) of the total cattle-days on pasture.

Although no other treatment produced higher average returns to land, labor, and management than did the check, returns from the $\mathrm{N}$-fertilized pastures were $29 \%$ higher in 1983 than returns from the check pastures. These increased returns were attained by a combination of a favorable growing season which produced a large increase in forage when $\mathrm{N}$ was applied, and a high stocking rate, particularly early in the grazing season, which efficiently converted forage into cattle gains. Nitrogen increased forage production in other years, but low stocking rate and/or increased stocking rate late in the grazing season did not allow maximum gains and returns. 


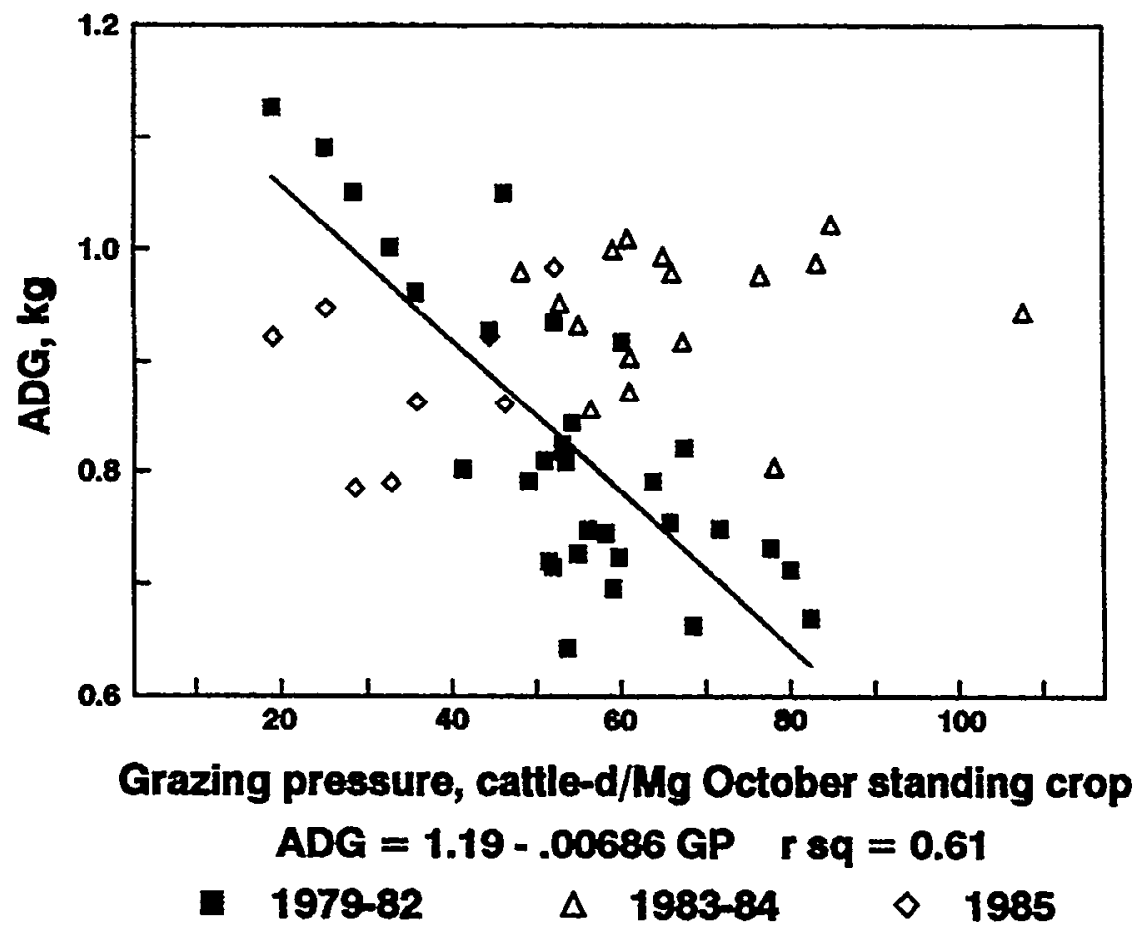

Figure 2. Average daily gain (ADG) vs. grazing pressure (GP) of cattle grazing shortgrass prairie. Response of ADG to GP did not differ significantly among control pastures and pastures receiving $\mathrm{N}$, atrazine, or $\mathbf{N}+$ atrazine.

\section{Conclusions}

The most meaningful comparisons of profitability should be made at optimum grazing pressures and stocking strategies. Optimum grazing pressures would have been achieved under heavy stocking early in the season and lighter stocking later. In 1983 and 1984, when pastures were stocked in this way, grazing pressures on all treatments were below the critical grazing pressure, and the data were insufficient for the development of the necessary grazing pressure $\times$ gain equations (Hart et al. 1988). Optimum grazing pressures and returns would be somewhat higher than those employed in this study, and it is possible that application of nitrogen or atrazine might be profitable at optimum grazing pressures.

\section{Literature Cited}

Allinson, D. W. 1972. Influence of simazine on yield and quality components of reed canarygrass. Agron. J. 64:530-535.

Ashby, M.M., R H. Hart, and J.R. Forwood. 1993. Plant community and cattle responses to fifty years of grazing on shortgrass prairie. USDA-ARS RRRU-1. Rangeland Resources Research Unit, Cheyenne, Wyo.

Bement, R.E. 1969. A stocking-rate guide for beef production on bluegrama range. J. Range Manage. 22:83-86.

Bridges, W. 1992. The Fence Post, vol. 13, nos. 18-43.

Bridges, W. 1993. The Fence Post, vol. 14, nos. 18-43.

Currie, P.O., J.D. Volesky, T.O. Hilken, and R.S. White. 1987. Selective control of annual bromes in perennial grass stands. I. Range Manage. 40:547-550.

Donart, G.B., E.E. Parker, R.D. Pieper, and J.D. Wallace. 1978.
Nitrogen fertilization and livestock grazing on blue grama rangeland, p. 614-615. In: D. N. Hyder (ed.), Proc. Ist Int. Rangel. Cong. Soc. Range Manage., Denver, Colo.

Dwyer, D.D., and J.G. Schickendanz. 1971. Vegetation and cattle response to nitrogen-fertilized rangeland in south-central New Mexico. New Mexico State Univ. Agr. Exp. Sta. Res. Rep. 215:1-5.

Hart, R.H., M.J. Samucl, P.S. Test, and M.A. Smith. 1988. Cattle, vegetation, and economic responses to grazing systems and grazing pressure. J. Range Manage. 41:282-286.

Houston, W. R. 1977. Species susceptibility to atrazine herbicide on shortgrass range. J. Range Manage. 30:50-52.

Houston, W.R., and D.H. van der Sluijs. 1973. Increasing crude protein content of forage with atrazine on shortgrass range. USDA-ARS Prod. Res. Rep. 153.

Hruschka, H.W. 1973. Systematic application of Duncan's multiple range test to biological data. USDA Agr. Res. Serv. ARS-NE-6.

Hyder, D.N., and R.E. Bement. 1964. Sixweeks fescue as a deterrent to blue grama utilization. J. Range Manage. 17:261-264.

Hyder, D.N., R.E. Bement, E E. Remmenga, and D.F. Hervey. 1975. Ecological responses of native plants and guidelines for management of shortgrass range. USDA Tech. Bull. 1503.

Hyder, D.N., W.R. Houston, and J.B. Burwell. 1976. Drought resistance of blue grama as affected by atrazine and $\mathrm{N}$ fertilizer. J. Range Manage. 29:214-216.

Jose, D., L. Bitney, D. Duey, P. Miller, J. Robb, and L. Sheffield. 1985. Estimated crop and livestock production costs. Nebraska Coop. Ext. Serv. Ext. Circ. 84-872.

Klipple, G.E. 1964. Early- and late-season grazing versus season-long grazing of shortgrass vegetation on the central Great Plains. USDA Forest Serv. Res. Paper RM-11.

Klipple, G.E., and D.F. Costello. 1960. Vegetation and cattle responses to different intensities of grazing on short-grass ranges on the Central Great Plains. USDA Tech. Bull. 1216.

McCollum, F.T., R.L. Gillen, D.M. Engle, and G.W. Horn. 1990. Stocker cattle performance and vegetation response to intensive-early 
stocking of Cross Timbers rangeland. J. Range Manage. 43:99-103.

McConnell, S.G., and S.S. Waller. 1986. Subirrigated meadow response to application of nitrogen, phosphorus and atrazine. Agron. J. 78:629-632.

Mott, G.O., and H.L. Lucas. 1952. The design, conduct, and interpretation of grazing trials on cultivated and improved pastures. Proc. 6th Int. Grassl. Cong. 2:1380-1385.

Owensby, C.E., R. Cochran and E.F. Smith. 1988. Stocking rate effects on intensive-early stocked Flint Hills bluestem range. J. Range Manage. 41:483-487.

Rauzi, F., R.L. Lang, and L.I. Painter. 1968. Effects of nitrogen fertilization on native rangeland. J. Range Manage. 21:287-291.

Retzlaff, R.E.J., L.A. Daigger and W.J. Moline. 1974. Fertilizing native range-production costs and returns. Univ. Nebraska Coop. Ext. Serv. \& Instit. Agr. \& Natur. Sci. EC 74-683 Rev., Lincoln, Nebr.

Ries, S.K. 1976. Subtoxic effects on plants, p. 313-344. In: L. A. Audus (ed.). Herbicides: Physiology, Biochemistry, Ecology, vol. II, 2nd ed. Academic Press, N.Y.

Sands, M., and J. Robb. 1993. Ranch/farm markets. Colo. Rancher \& Farmer 47:28, 31 .

Shoop, M.C., and E.H. Mcllvain. 1963. The micro-unit forage inventory method. J. Range Manage. 16:172-179.

Shoop, M.C., G.P. Rupp, C.V. Kimberling, and B.W. Bennett. 1984. $\mathrm{K}-\mathrm{R}$ spaying, anabolic agent (zeranol) and pasturing spayed heifers with steers: their effect on growth of stocker cattle. Proc. West. Sect. Amer. Soc. Anim. Sci. 35:134-137.

Smith, E.F., and C.E. Orensby. 1978. Intensive-early stocking and season-long stocking of Kansas Flint Hills range. J. Range Manage. 31:14-17.

Tapia, M.E. 1973. Effects of atrazine herbicide, nitrogen and phosphorus fertilizers on nutritive value of shortgrass range and blue grama grass [Bouteloua gracilis (H.B.K.) Lag. ex Steud.] Ph.D. Diss., Colorado State Univ., Ft. Collins, Colo. (Diss. Abstr. Intl. 34:5154B).

Waller, S.S., and D.K. Schmidt. 1983. Improvement of eastern Nebraska tallgrass range using atrazine or glyphosate. J. Range Manage. 36:87-91.

\section{Rangeland Monitoring}

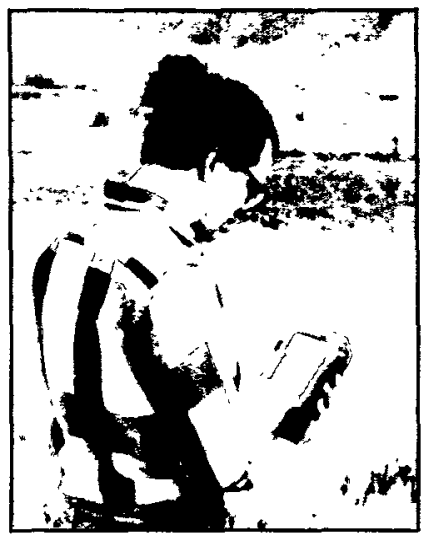

With a Field Computing System You Will:

- Speed up Data Collection

- Reduce Errors

- Generate Reports Faster

Juniper Systems provides field computing solutions for rangeland monitoring and trend studies. We offer:

$\downarrow$ Rugged Field Computers

- Rangeland Monitoring Method Software: Daubenmire Six Cover Class

Nested Plot Frequency

Step-Point Transect

Key Forage Plant

- Bar Code Wands and Templates

- Training and Support

- Custom Programming for Your Application

With a field computing system, you will do more work with fewer people and get faster, more accurate results. Include one in your budget today!

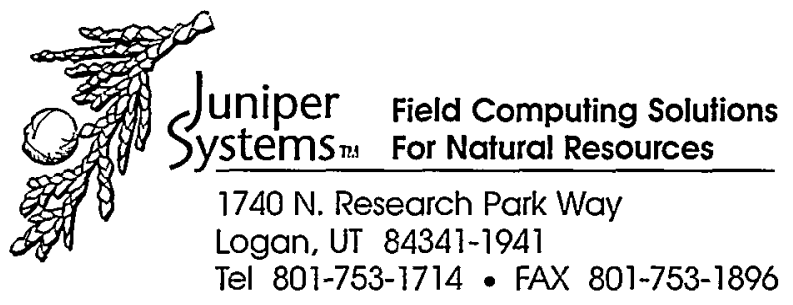

